\title{
FIC Test Performance on Multi-Resistant Bacteria Isolated From Different Environments
}

\author{
$*{ }^{1}$ Khaldi A, ${ }^{2}$ Maghdouri N, ${ }^{3}$ Tir touil A, ${ }^{4}$ Meddah B
}

\begin{abstract}
The emergence of multi-resistant bacteria (BMR) represents a major health problem worldwide. Among these bacteria, the most encountered are those that express beta-lactamase (ESBL) extended spectrum. The alternative therapy implementation represents an alternative solution to fight against this health risk. The purpose of this study is to investigate the bacterial diversity, antimicrobial resistance, types of beta-lactamases and evaluate the antibacterial effect of the extract of A. halimus on pathogens resistant bacteria isolated from clinical infection, food and environmental. 115 pathogenic strains were isolated from different samples (Staphylococcus aureus, E. coli, Salmonella sp, Clostridium sp), respectively. All isolates are strains of beta-lactamase. The three Atriplex hamilus extracts, essential oil, hydrometanolic and acetate have a low return linked to the characteristics of the plant itself. The extracts showed higher antibacterial activity. The essential oil exerts an antagonistic effect on all strains pathogenic with $200 \mathrm{ul} / \mathrm{ml}$ while the extract of hydrometanolic acetate and showed an inhibitory effect at a concentration of $300 \mathrm{mg} / \mathrm{ml}$ depending on the strain tested. the results suggest that the extracts of Atriplex hamilus could be a potential treatment alternative for resistant bacteria.
\end{abstract}

Keywords: Atriplex halimus extract, beta-lactamase, an antibacterial activity.

\section{INTRODUCTION}

The phenomenon of bacterial antibiotic resistance has been a strong interest in the scientific community since it represents a risk to public health. It reduces the effectiveness of antibiotics used as first-line and complicates the management of the patient. The development of resistance in bacteria animals can lead to food borne infections (Salmonella, Campylobacter) or opportunists (E. coli, Enterococcus sp., Staphylococcus aureus) is monitored in the context of an approach global public health. It is time to allocate efforts to find an alternative to the emergence of microbial resistance by new bioactive natural compounds from traditional plant medicine. Atriplex hamilus species are dominant in many arid and semi-arid regions of the world, particularly in habitats that combine relatively high soil salinity with aridity [1][2]. The plant is traditionally used in Algeria especially in folk medicine in the treatment of many diseases and infections.

\footnotetext{
1,2,3,4 Laboratoire de Bioconversion, Génie Microbiologique et Sécurité Sanitaire, Faculté SNV, Univ. Mascara-29000-Algérie, * Corresponding author: KHALDI Amina, , Phone: 002135529821 43, Fax: 00213457070 03, E-mail address: amkhaldia@ hotmail.com
}

The aim of this study is to describe the bacterial diversity from clinical infection and food samples, antimicrobial resistance, types of beta-lactamases and to evaluate the effect of the extracts of Atriplex halimus on pathogenic multi drug resistant bacteria isolated from clinical infection and food samples.

\section{MATERIALS AND METHODS}

\section{A. Plant Materials}

Fresh Atriplex halimus leaves were collected from the region of Mascara in west Algerian in April 2014. The plant material was identified according to African flowering plants database, and by local expert. A voucher specimen (\#226) (Fig.1) was deposited at the herbarium center of the department of Biology, Mascara University (North West of Algeria) for future reference. The leaves were dried for 3 weeks in darkness at room temperature.

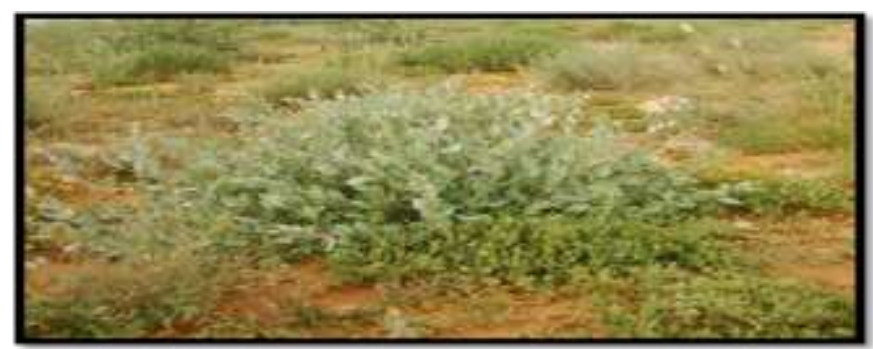

Fig. 1 : Fresh Atriplex halimus cultivated Mascara (North West of Algeria)

\section{Preparation of extract}

For extraction of the essential oils, the dried plant material $(1 \mathrm{~kg})$ was subjected to hydro-distillation using a Clevengertype extraction device. This technique is based on the power which has water vapor transport to the essential oils by stream distillation of water for $2 \mathrm{~h}$ at $95^{\circ} \mathrm{C}$ [3]. The methanolic and acetate extracts were prepared according to the method described by Escarpa and Gonzalez [4]with little modification .The plant (50gr) were grinded and homogenized in a blinder and extracted with $250 \mathrm{ml}$ of $80 \%$ methanol or $60 \%$ acetone containing $1 \%$ of 2,6-du-tert-butyl-4-methylphenol, using an ultrasonic bath. The extraction was repeated three times. The same extracts were pooled and filtered through Whatman No 1 filter paper and evaporated by using a rotary evaporator to give the crude dried extract. The yield of each extract was 
estimated according the equation: $\mathrm{Y}(\%)=(\mathrm{m} / \mathrm{mo}) \times 100$ [3]. Finally the extracts obtained were sterilized by filtration, kept in sterile tube and protected from light at $+4^{\circ} \mathrm{C}$.

\section{B. Microbial samples collection}

Clinical samples were isolated from patients (aged between55 and 65 with varied pathology) in surgical service (Table). Food samples were carried out under aseptic conditions from three different sources (Table 1). All samples were caught during a period between Mars and September 2013. They were collected aseptically and transported to the laboratory in a cooler at $+4{ }^{\circ} \mathrm{C}$ for Microbial analysis.

\begin{tabular}{|l|c|c|}
\multicolumn{2}{c|}{ TABLE 1: ORIGIN OF MICROBIAL STRAINS } \\
\hline \multicolumn{1}{|c|}{ Site } & Clinical infection & Food Samples \\
\hline \multirow{4}{*}{$\begin{array}{l}\text { Sampling } \\
\text { Nature }\end{array}$} & anal fissure & raw milk \\
\cline { 2 - 3 } & Urinary infection & poultry meat \\
\cline { 2 - 3 } & & Water consumption \\
\cline { 2 - 3 } & Bone abscess & Fish intestine \\
\cline { 2 - 3 } & & Bovine intestine \\
\hline
\end{tabular}

\section{Identification of pathogenic strains}

Samples were analyzed for aerobic bacterial content by cultures on a series of non-selective and selective media (Blood agar, Chapman medium, Hektoen medium, Nutritive agar medium, MRS medium), incubated at $37^{\circ} \mathrm{C}$ for $24 \mathrm{~h}, 48 \mathrm{~h}$ and up to $72 \mathrm{~h}$ according to the investigated strains and with anaerobic condition in the atmosphere for Clostridium. Followed by Gram coloration and biochemical test using automate microbiological system identification (API system). The strains isolated from these standard culture procedures were identified with commercials kits (API Staph, API 20 E and others biochemical tests for Clostridium sp [5].

\section{Inoculums' preparation}

Nutriment broth [5] was used for growing strains and diluting suspensions. Bacterial strains were grown to exponential phase in nutriment broth at $37^{\circ} \mathrm{c}$ for $18 \mathrm{~h}$ and adjusted to a final density of $2 \times 108 \mathrm{CFU}$ by diluting fresh cultures and comparison to Mac Farland standards $(\mathrm{OD} 650=0.7)[6]$

\section{Antibiotic susceptibility testing}

Resistance towards antibiotics was assessed for each strain with the disc diffusion method [7] and bacterial growth on Muller Hilton Agar plates. The antibiotic tested for Staphylococaceae, were Oxacillin $(10 \square \mathrm{g})$, Erythromycin $(15 \mu \mathrm{g})$, Spriramycin $(10 \mu \mathrm{g})$, Chloramphenicol $(30 \mu \mathrm{g})$, Tetracyclin $(30 \mu \mathrm{g})$, for Enterobacteriaceae were Ampicillin $(10 \mu \mathrm{g})$, Gentamicin $(10 \mu \mathrm{g})$, Aztreonam $(30 \mu \mathrm{g})$, Colistin $(10 \mu \mathrm{g})$, Tetracyclin $(30 \mu \mathrm{g})$, Chloramphenicol $(30 \mu \mathrm{g})$, for Clostridiaceae were Cefazolin $(10 \mu \mathrm{g})$ Nalidixic Acid $(30 \mu \mathrm{g})$,

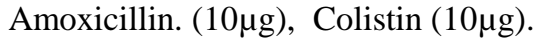

\section{Search of beta-lactamases}

Only strain resistant to one or more than antibiotic was selected for beta-lactamases research. Phenotypic demonstration of the presence of a $\beta$-lactamase extended spectrum in Enterobacteriaceae is to highlight an image of a disk synergy between third-generation cephalosporin and clavulanic acid. Apply on Mueller Hinton agar [5]previously seeded with the test strain, a disc of ceftazidime, aztreonam or cefotaxime and amoxicillin + clavulanic acid disk (AMC), a 1 $1 / 2 \mathrm{~cm}$.

Search beta-lactamases in Staphylococcus sp was conducted by iodometric test [8]. It consists of a complex of iodine discoloration-starch due to the reduction of iodine by penicilloic acid from the hydrolysis of penicillin $G$ by beta lactamase.

\section{Antimicrobial activity assay byMinimum Inhibitory Concentration (MIC)}

The minimal inhibition concentration (MIC) values were determined in all strains isolated from clinical infection and food using a microdilution method according to Howaida [9] using 96 well microtiter plates. The MIC was defined as the lowest concentration of the extracts inhibiting the growth of microbial strains. The growth media employed was nutrient broth. The highest concentration of extracts (essential oil $=$ $500 \mu \mathrm{l}$, methalolic and acetate $=500 \mathrm{mg})$. Nutrient broth $(50 \mu \mathrm{l})$ according to strain tested were distributed from the 2nd to the 12th well, a volume of sterile extracts of Atriplex hamilus was added into the 1st test well, and the $50 \mu 1$ of scalar dilution was transferred from 2 nd to the 12th well. Finally, $50 \mu \mathrm{l}$ of calibrated bacterial suspension were added to each well. Erythromycin $(10 \mu \mathrm{g} / \mathrm{ml})$ was used as positive control, methanol served as negative control. Growth was estimated by measuring well optical density at $620 \mathrm{~nm}$ using a microplate Absorbance Reader Sunrise (Tecan Australia GmbH RC/TS/TS) comparatively to control wells (nutriment both + inoculum). The plate were agitated and incubated at $37^{\circ} \mathrm{C}$ for $48 \mathrm{~h}$. The lowest concentration showing no culture was considered as the MIC and it's express as $(\mu \mathrm{l} / \mathrm{ml}$, or $\mathrm{mg} / \mathrm{ml})$.

3. Statistical analysis

The tests were conducted twice for each sample and the mean of Colony Forming Unit (CFU) count was determined. The results are presented as the mean +- SD of three replicates. For antimicrobial activity, we consider Log CFU more than $\log 1$ as significant.

\section{5-Microdilution method:}

The MIC of each extract was determined by the microdilution method using a 96 then.

- $50 \mathrm{~L}$ of sterile nutrient broth was then distributed in all, then added in the years two then $50 \mathrm{~L}$ of the extract $\mathrm{A}$. halimus has a concentration After homogenization, taken $50 \mathrm{~L}$ in the third well by performing a dilution decreasing by $1 / 2$ and so on until the twelfth well. In the end, 10 .mu.l of the microbial suspension (106 CFU / $\mathrm{ml}$ ) is placed in each and. 


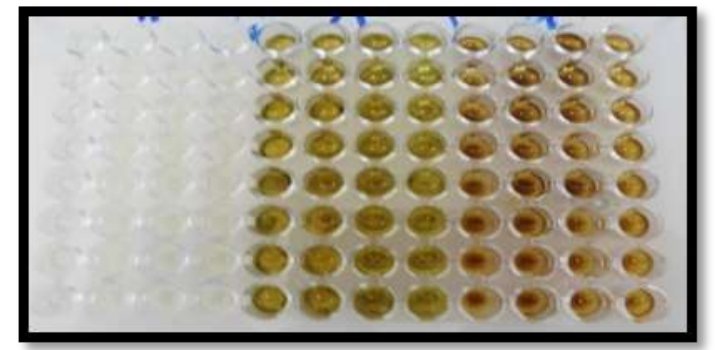

- The microplate is covered incubated at $37^{\circ} \mathrm{C}$ for 24 to 48 hours.

\section{Positive Control}

Making a positive control by the antibiotic erythromycin $(15 \mu \mathrm{g})$ for bacterial strains and gentamicin for Gram-positive bacilli.

\section{Negative Control}

The methanol will and DMSO are considered as a negative control to ensure that the negative effect of these two solvents on microbial growth.

Incubation in the same previous conditions. The absorbance is measured by a microplate reader (PRINTER).

\section{Determination of CMI}

The MIC (minimum inhibitory concentration) is the lowest concentration responsible for the inhibition of microbial growth (Guinoiseau. 2010). It is determined after having carried out the kinetics of microbial growth curves.

\section{Determination of CMB}

The MBC (minimum bactericidal concentration) is the lowest concentration able to kill more than $99.9 \%$ of the initial microbial inoculum (less than $0.01 \%$ of survivors).

The MIC and MBC are determined each microbial growth without well then deposited "streaked" on a nutrient agar for bactériennes.les cash boxes are seeded 24 hours at $37^{\circ} \mathrm{C}$.

6-Mechanisms of action of Atripex halimus extracts on multiresistant strains

\section{6-1 Lyse strains after contact with extracts of A. halimus Principle}

To appreciate the release of cell contents to $260 \mathrm{~nm}$, the washed bacterial suspension is treated with extracts inhibitory concentration (essential oil, polyphenolic compound).

Applying the technique (K.S Rosenthal et al., 1976).

1. Wash the tested strains

Bacterial culture obtained after 24 hours of incubation was centrifuged at $400 \mathrm{~g}$ for 25 minutes, the supernatant is removed and the bacterial pellet is resuspended in a volume of sterile PBS phosphate buffer (Appendix) equal to the initial volume of the bacterial culture. The suspension thus obtained is called washed suspension.

2. Setting ET on the tested strains

To verify the adsorption of essential oils and their constituents on the strains studied, the washed suspensions were treated for 20 minutes in a concentration of ET subinhibitrice A. halimus, then centrifuged at $12,000 \mathrm{~g}$ for 2 minutes.

The absorbance at $280 \mathrm{~nm}$ of the supernatant is measured in comparison with EOs suspensions or polyphenolic extracts spun down in the same way without prior contact with bacteria.

3. Microscopic examination of strains tested

Microscopic verification is done after Gram staining.

Observation of bacteria treated with a scanning electron microscope (SEM).

After an hour of treatment with bactericidal concentrations of extracts of the plant, bacteria are prefixed with a glutaraldehyde solution diluted to $2 \%$ in PBS for one hour at 4 ${ }^{\circ} \mathrm{C}$. A post-fixation is done by osmium tetroxide $2 \%$ diluted in PBS for 30 minutes at $4{ }^{\circ} \mathrm{C}$. After each fixation, bacteria were washed twice in PBS buffer.

Then, the bacteria are dehydrated " at the critical point " in the presence of liquid $\mathrm{CO} 2$ under a pressure of 95 bar. The samples are covered with a gold layer by sputtering using a metallizer before being examined with a scanning electron microscope

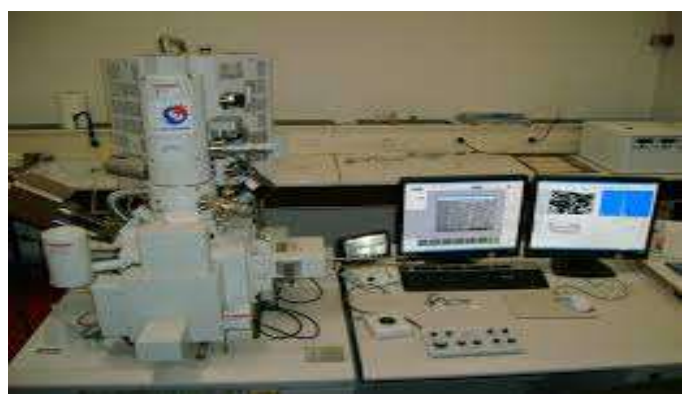

Method of synergy between the antibiotic and the extract A. halimus (method FIC)

Principle

In order to seek a possible synergy (plant extract + ATB), combinations between the plant extract (ET, EM, EA) e antibiotics (amoxicillin, penicillin) were tested to calculate the FIC index (Fraction Inhibitory Concentration). (Remmal A. et al., 1993)

\section{Processing solid medium (preliminary test)}

The Petri dish is first seeded on the surface by a fresh suspension of the test strain (24 hour culture) and then proceed to the development of cavities with sterile cookie cutter in the agar medium cast and solidified box . Filling these cavities with a volume of 100 .mu.l of ET or polyphenolic extracts and ATB (inhibitory concentration) that will diffuse into the agar and incubation is performed after the observation of inhibition diameters.

\section{Micromethod}

Technique

- Prepare different concentrations of extracts (essential oil, methanoic extract and aqueous extract) and the antibiotic (B), the first column and the last row of the microtiter plate are provided for MIC determination of every single antibacterial agent ;

Then horizontally distribute $50 \mathrm{ml}$ of each concentration of A vertically and $50 \mathrm{ml}$ of each concentration B finally add 90 .mu.l of nutrient broth.

\section{Preparation of bacterial inoculum}

Prepared from a pure culture of bacteria in the exponential phase, a suspension of the strain to be studied, in 5 to $10 \mathrm{ml}$ of 
sterile saline (or $\mathrm{BN}$ ), a density equivalent to $0.5 \mathrm{MF}$ (108 $\mathrm{CFU} / \mathrm{ml}$ ); dilute this suspension opacity $0.5 \mathrm{MF} 10-1$; then inoculate the wells of the microplate with 10 .mu.l of bacterial suspension to a final concentration of $5.105 \mathrm{CFU} / \mathrm{ml}$ at the end incubated at $37^{\circ} \mathrm{C}$.

After 18 hours of incubation, each note in the first row tube containing $\mathrm{A}+\mathrm{B}$, without visible growth;

-To Determine, in each of these wells fractions inhibitory concentrations FIC A and B or A and FIC FIC B;

-The Value of the association is quantified by the FIC index; FIC A: corresponds to the IJC report of A and B on the MICs single $A$;

FIC B: is the ratio of the MIC B with A on the MIC B alone;

FIC $=$ FIC A + FIC B $=($ MIC A with $\mathrm{B} / \mathrm{MIC}$ alone $\mathrm{A})+$ (MIC B with A / B MIC only)

If the FIC index is less than 0.75 , the combination is synergistic,

It is additive if it is equal to 1 ,

Indifferent if it is between 1 and 2,

Antagonist if it is greater than 2 .

\section{Statistical analysis}

All experiments were performed in duplicate, the frequency of isolation of germs was determined in percentage, the results were expressed as $\mathrm{X} \pm \mathrm{SEM}$

For the determination of the antibacterial activity of plant extracts (H.E, E.M, E.A), a difference of $1 \log$ CFU / $\mathrm{ml}$ is considered significant (Rooly et al., 1993).

\section{RESULTS AND DISCUSSION}

\section{A. Extraction of Essential oil from Atriplex halimus}

The essential oil of Atriplex halimus obtained from the aerial part is yellow, liquid appearance with a strong odor resulting from the salinity. The plant has a low yield of $0.06 \%$ with neutral $\mathrm{pH}$ of 7.1. The low yield may be due to various factors such as the characteristics of the plant as it grows in saline soils [10] which may affect the growth and yield of the plant [11]. Furthermore, salinity causes an increase in the epidermal thickness, the thickness of the mesophyll, palisade cells of the length, the diameter of palisade cells of the leaves in Atriplex halimus [12]. Salinity also reduces the intercellular space in the sheets [13]. In addition, low levels of essential oil may be due to the method of extraction or the time and place of harvest. This species originated in Bechar provided with the same method of extracting essential oil content of $0.02 \%$ of the aerial part of the plant [14]. These differences may be due to factors related to the ecosystem (climate, soil type, rainfall, etc.), the time of harvest and drying time.

\section{B. Methanolic and Acetate extraction}

The result of this experiment allowed the production of two different extracts its appearance and color with $\mathrm{pH} 6.63$. The methanol extract is dark green with a solid look after evaporation, with a yield equal to $0.84 \%$. A study was made by BELYAGOUBI [15] indicating that $24 \%$ yield of the same species and the same part used for extraction. This difference in the level of performance always goes to the origin and characteristics of the plant. While the acetate extract obtained is brown with a yield of $0.052 \%$ and a $\mathrm{pH}$ of 8.07 . This results were similar than obtained by CHIKHI ILYAS,[14]

\section{Bacterial Species distribution}

13 Strains from clinical infection and Food samples were isolated and described in Table 2

TABLE II: PATHOGENIC BACTERIA ISOLATEd FROM CLINICAL INFECTION AND FOOD

\begin{tabular}{|c|c|c|c|}
\hline Site & samples & $\begin{array}{l}\text { Pathogenic strain } \\
\text { isolate }\end{array}$ & Denomination \\
\hline \multirow{3}{*}{$\begin{array}{l}\text { Clinical } \\
\text { infection }\end{array}$} & anal fissure & Clostridium sp & Clostridium .sp \\
\hline & $\begin{array}{l}\text { Urinary } \\
\text { infection }\end{array}$ & E.coli & E.coli .1 \\
\hline & Bone abscess & $\begin{array}{l}\text { Staphylococcus } \\
\text { aureus }\end{array}$ & S. aureus .1 \\
\hline \multirow{5}{*}{$\begin{array}{l}\text { Food } \\
\text { Samples }\end{array}$} & raw milk & $\begin{array}{l}\text { Staphylococcus } \\
\text { aureus }\end{array}$ & S. aureus .2 \\
\hline & poultry meat & $\begin{array}{l}\text { Staphylococcus } \\
\text { aureus } \\
\text { E.coli } \\
\text { Salmonella sp } \\
\end{array}$ & $\begin{array}{l}\text { S. aureus.3 } \\
\text { E.coli. } 2 \\
\text { Salmonella sp .1 }\end{array}$ \\
\hline & $\begin{array}{l}\text { Water } \\
\text { consumption }\end{array}$ & $\begin{array}{l}\text { Staphylococcus } \\
\text { aureus } \\
\text { E.coli }\end{array}$ & $\begin{array}{l}\text { S.aureus. } 4 \\
\text { E.coli. } 3\end{array}$ \\
\hline & Fish intestine & $\begin{array}{l}\text { Staphylococcus } \\
\text { aureus } \\
\text { E.coli }\end{array}$ & $\begin{array}{l}\text { S. aureus.5 } \\
\text { E.coli.4 }\end{array}$ \\
\hline & $\begin{array}{l}\text { Bovine } \\
\text { intestine }\end{array}$ & $\begin{array}{l}\text { Salmonella sp } \\
\text { E.coli }\end{array}$ & $\begin{array}{l}\text { Salmonella sp. } 2 \\
\text { E.coli. } 5\end{array}$ \\
\hline
\end{tabular}

D. Antibiotic susceptibility test

According to the table 3, the bacterial strains isolates were multidrug-resistant to $100 \%$. This level of resistance is a consequence of many factors, including misuse of antibiotics; increased severity of the status of hospitalized patients; lack of adherence; too short or sub-therapeutic dose; unconfirmed bacterial infection and improper use of antibiotics [16]. Table 3:

\begin{tabular}{|c|c|c|}
\hline Results of & Antibiotics & Test \\
\hline $\begin{array}{c}\text { Antibiotic } \\
\text { Susceptibility tests } \\
\text { bacteria }\end{array}$ & & sensibility \\
\hline S. aureus $1,2,3,4,5$ & $\begin{array}{l}\text { Ampicillin } \\
\text { Oxacillin } \\
\text { Erytromycin } \\
\text { Gentamycin }\end{array}$ & $\mathrm{R}$ \\
\hline E.coli $1,2,3,4,5$ & $\begin{array}{l}\text { Spiramycin } \\
\text { Gentamicin } \\
\text { Colistin } \\
\text { Amoxicillin }\end{array}$ & $\mathrm{R}$ \\
\hline Salmonella sp 1,2 & $\begin{array}{l}\text { Gentamicin } \\
\text { Colistin } \\
\text { Amoxicillin }\end{array}$ & $\mathrm{R}$ \\
\hline \multirow[t]{2}{*}{ Clostridium.sp } & $\begin{array}{l}\text { Colistin } \\
\text { Nalidixic Acid } \\
\text { Cefazolin }\end{array}$ & $\mathrm{R}$ \\
\hline & Amoxicillin & \\
\hline
\end{tabular}




\section{E. Determination of beta-lactamases}

The search for beta-lactamase was performed only in E. coli and Staphylococcus aureus with resistance to antibiotics are $100 \%$. According to the results, all tested strains from E.coli of produce BLSEs. These enzymes are responsible for the multidrug resistance strains overlooked different antibiotics. This result shows the prevalence of the emergence of antibiotic-producing bacteria including BLSEs Enterobacteriaceae [17]. Producing strains BLSEs were often associated with nosocomial outbreaks associated with several risk factors such as ICU admission. The spread of plasmids (plasmid epidemics) and / or other mobile genetic elements is among the main causes for the emergence of BLSEs producing bacteria [18]. Because of the abundance and ubiquity of E. coli, several recent studies have mounted it is the species most affected by the emergence of new BLSEs [19]. While, in Staphylococcaceae, the presence of enzyme was achieved through the iodometric test which proved positive for strains with penicillinase phenotype. These enzymes may also acquire resistance acquired through mobile genetic elements (plasmids, transposons or integrons). Penicillin's production strains showed resistances to antibiotics belong to the family of amino pinicilines (AMX example) [20]. Study of antibacterial activity by the combination of extracts A. halimus and antibiotics (test FIC)

\section{Method of Dissemination}

In order to improve efficiency and the antibacterial effect of antibiotics on pathogens and producing bacteria of BLSEs, we conducted a test combination of extracts A. halimus and tested antibiotics in antibiogram. According to the primary results shows an improvement in the inhibition zones (see Table 11), we can deduce that there is a synergy between the extracts and antibiotics

TABLE III: DiAmETERs OF INHIBITION ZONES AFTER THE ASSOCIATION BETWEEN EXTRACTS AND ANTIBIOTICS.

\begin{tabular}{|c|c|c|c|c|c|c|c|c|}
\hline & \multicolumn{8}{|c|}{ Diamètres (mm) } \\
\hline & S.aursus & $\begin{array}{l}S A I \\
V M\end{array}$ & $\begin{array}{l}S A I \\
M M\end{array}$ & $E . C$ & \begin{tabular}{|l|}
$E . C$ \\
(lait)
\end{tabular} & $\begin{array}{l}\text { Clostrid } \\
\text { ium,sp }\end{array}$ & $\begin{array}{l}\text { Salmom } \\
\text { glas sp }\end{array}$ & $\begin{array}{l}\text { Shégi } \\
\text { lla.sp. }\end{array}$ \\
\hline H.E & $\underline{11}$ & $\underline{11}$ & 8 & $\underline{12}$ & $\underline{10}$ & $\underline{12}$ & $\underline{10}$ & $\underline{11}$ \\
\hline $\begin{array}{l}\text { E. } \\
\text { M }\end{array}$ & $\underline{12}$ & - & - & $\underline{10}$ & $\underline{10}$ & $\underline{10}$ & $\underline{9}$ & $\underline{9}$ \\
\hline E.A & 9 & - & $\underline{10}$ & $\underline{10}$ & - & $\underline{12}$ & $\underline{10}$ & $\underline{11}$ \\
\hline
\end{tabular}

An improvement appeared in the inhibition exercised by the association between essential oil and antibiotic on the tested strains (E.coli, E.coli of milk origin, Salmonella.sp, Shegilla.sp, S.aureus, SA.IMM, Clostridium.sp) where the diameter increased by $2 \mathrm{~mm}$ is realized between 10 and 12 $\mathrm{mm}$.

For the methanol extract, a positive association was established with the antibiotic that is reflected in an improvement in the inhibition diameter reaches $12 \mathrm{~mm}$ in S.aureus and varied between 9 and $10 \mathrm{~mm}$ for other strains tested. This study is approved by the A.Elbashiti Tarek et al (2011), synergy was found between the methanol extract and
Amikacin on the E. coli strain with a zone of inhibition of 22 $\mathrm{mm}$. On S.aureus, a synergistic effect is shown between the methanol extract and some antibiotics whose most remarkable combination with minocycline where the zone of inhibition reaches $48 \mathrm{~mm}$.

To the aqueous extract, inhibition is exerted by the combination of the extract and antibiotics on Clostridium.sp, Shegilla.sp, Salmonella.sp, E.coli, S.aureus and SA.IMM whose diameter is varied between 9 and $12 \mathrm{~mm}$. The study A.Elbashiti Tarek and his staff on S. aureus and E. coli (2011), indicates by aillor no inhibitory effect when there is an association between the aqueous extract with the antibiotic tested.
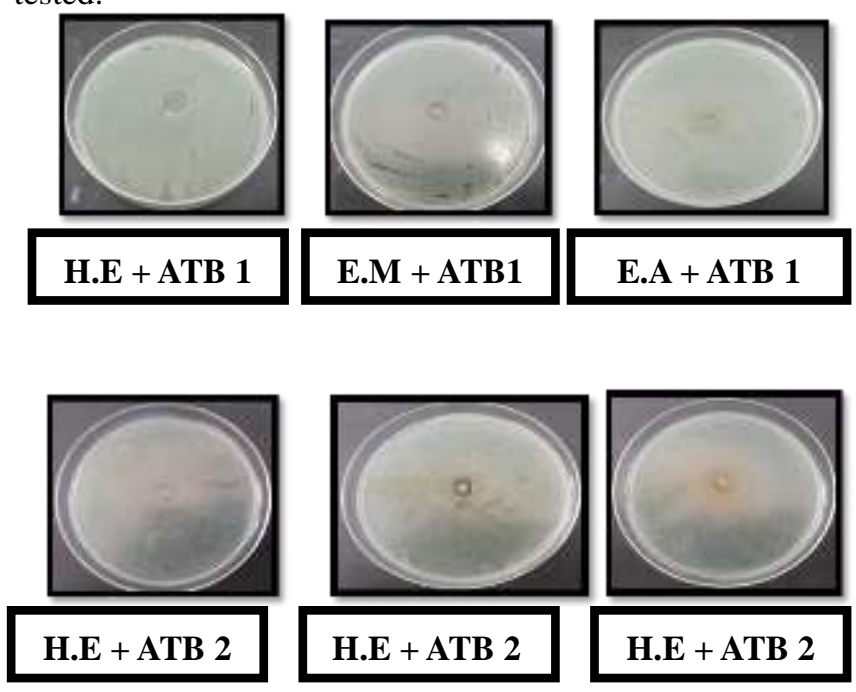

Plate 13: synergy test applied on the strains tested

ATB 1 : Pinicilline ATB2 :Amoxicilline

\section{Technic of microdilution}

To verify the nature of relationship between the extracted A. halimus and tested antibiotics was applied a microdilution then calculate the fraction inhibition (FIC) and compare with the standards of this test.
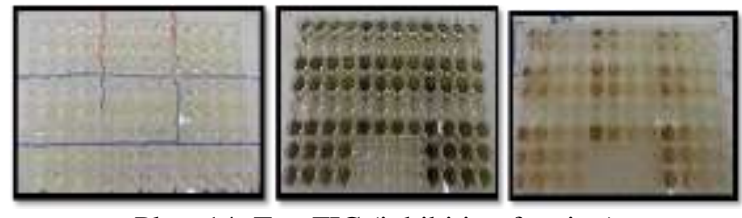

Plate 14: Test FIC (inhibition fraction).

FIC calculation of each extract with the antibiotic

To determine the type of relationship between each extract and antibiotics, we calculate what is called the fractional inhibition (FIC) (see tables below if). 


\section{Essential oil}

Table IV: Mic Values Of E.O With The ANTiBiotic

\begin{tabular}{|l|l|l|l|l|}
\hline strains & $\begin{array}{l}\text { MIC of } \\
\text { E.O } \\
(\mu \mathrm{l} / \mathbf{m l})\end{array}$ & $\begin{array}{l}\text { MIC of } \\
\text { ATB } \\
(\mu \mathrm{g} / \mathrm{ml})\end{array}$ & $\begin{array}{l}\text { MIC of E.O } \\
\text { with ATB } \\
(\mu \mathrm{l} / \mathbf{m l})\end{array}$ & $\begin{array}{l}\text { MIC of } \\
\text { l'ATB } \\
\text { with E.O } \\
(\mu \mathrm{g} / \mathbf{m l})\end{array}$ \\
\hline SA & 200 & 1 & $100(100 / 1)$ & $\begin{array}{l}0.5 \\
(0,5 / 50)\end{array}$ \\
\hline SA.IVM & 200 & 1 & $100(100 / 1)$ & $\begin{array}{l}0.5 \\
(0,5 / 50)\end{array}$ \\
\hline SA.IMM & 200 & 1 & $100(100 / 1)$ & $1(1 / 100)$ \\
\hline $\begin{array}{l}\text { Clostridiu } \\
\text { m.sp }\end{array}$ & 200 & 8 & $100(100 / 4)$ & $2(2 / 50)$ \\
\hline E.C & 200 & 8 & $100(100 / 4)$ & $2(2 / 50)$ \\
\hline E.C (lait) & 200 & 4 & $100(100 / 4)$ & $4(4 / 100)$ \\
\hline $\begin{array}{l}\text { Shegilla.s } \\
\text { p }\end{array}$ & 200 & 4 & $100(100 / 4)$ & $2(2 / 50)$ \\
\hline $\begin{array}{l}\text { Salmonel } \\
\text { la.sp }\end{array}$ & 200 & 4 & $100(100 / 4)$ & $2(2 / 50)$ \\
\hline
\end{tabular}

Table V: Calculation of the FIC INDEX Between H.E AND ATB

\begin{tabular}{|l|l|l|l|l|}
\hline Strains & FIC $_{\mathrm{EO}}$ & FIC $_{\mathrm{ATB}}$ & FIC $_{\mathrm{end}}$ & $\begin{array}{l}\text { Nature of the } \\
\text { relation between } \\
\text { E.O and ATB }\end{array}$ \\
\hline SA & 0,5 & 0,5 & 1 & Additive \\
\hline SA.IVM & 0,5 & 0,5 & 1 & Additive \\
\hline SA.IMM & 0,5 & 1 & 1,25 & Indifferent \\
\hline Clostridium.sp & 0,5 & 0,25 & 0,75 & Synergetic \\
\hline E.C & 0,5 & 0,25 & 0,75 & Synergetic \\
\hline E.C (lait) & 0,5 & 1 & 1,5 & Indifferent \\
\hline Shegilla.sp & 0,5 & 0,5 & 1 & Additive \\
\hline Salmonella.sp & 0,5 & 0,5 & 1 & Additive \\
\hline
\end{tabular}

The association between the extracted A. halimus and antibiotics adds a good effect for the inhibition of the strains tested. Synergy appeared in the combination of antibiotics and essential oil on Clostriduim.sp E.coli and hospital-acquired.

\section{Methanolic extract}

TABLE VI: MIC VALUES FOR M.E WITH THE ANTIBIOTIC

\begin{tabular}{|l|l|l|l|l|}
\hline Strains & $\begin{array}{l}\text { MIC of } \\
\text { M.E } \\
(\mathbf{m g} / \mathbf{m l})\end{array}$ & $\begin{array}{l}\text { MIC of } \\
\text { ATB } \\
(\mu \mathrm{g} / \mathrm{ml})\end{array}$ & $\begin{array}{l}\text { MIC of } \\
\text { M.E } \\
\text { With } \\
\text { ATB } \\
(\mathbf{m g} / \mathbf{m l})\end{array}$ & $\begin{array}{l}\text { MIC of ATB } \\
\text { with M.E } \\
(\mu \mathrm{g} / \mathrm{ml})\end{array}$ \\
\hline SA & 200 & 2 & $\begin{array}{l}50 \\
(50 / 0,5)\end{array}$ & $0,5(0,5 / 50)$ \\
\hline SA.IVM & 25 & 2 & $\begin{array}{l}50 \\
(50 / 0,5)\end{array}$ & $0,25(0,25 / 25)$ \\
\hline SA.IMM & 25 & 2 & $\begin{array}{l}100 \\
(100 / 1)\end{array}$ & $0,25(0,25 / 25)$ \\
\hline $\begin{array}{l}\text { Clostridi } \\
\text { um.sp }\end{array}$ & 100 & 8 & $50(50 / 2)$ & $1(1 / 25)$ \\
\hline $\begin{array}{l}\text { E.C } \\
\text { S. }\end{array}$ & 200 & 8 & $\begin{array}{l}100 \\
(100 / 4)\end{array}$ & $1(1 / 25)$ \\
\hline $\begin{array}{l}\text { E.C } \\
\text { (lait) }\end{array}$ & 50 & 8 & $25(25 / 1)$ & $2(2 / 50)$ \\
\hline $\begin{array}{l}\text { Shegilla. } \\
\text { sp }\end{array}$ & 200 & 8 & $\begin{array}{l}100 \\
(100 / 4)\end{array}$ & $8(8 / 200)$ \\
\hline
\end{tabular}

. TABle VII: CALCULATION OF THE FIC INDEX BETWEEN M.E AND ATB .

\begin{tabular}{|c|c|c|c|c|}
\hline Strains & FIC $_{\text {EMS }}$ & $\mathrm{FIC}_{\text {ATB }}$ & $\mathrm{FIC}_{\mathrm{FN}}$ & $\begin{array}{l}\text { Nature of the } \\
\text { relation between } \\
\text { l'M.E and ATB }\end{array}$ \\
\hline$S A$ & 0,25 & 0,25 & 0,5 & Synergetic \\
\hline$S A I V M$ & 2 & 0,125 & 2,125 & Antagonist \\
\hline$S A I M M$ & 4 & 0,125 & 4,125 & Antagonist \\
\hline $\begin{array}{l}\text { Clestidium } \\
\text { sp. }\end{array}$ & 0,5 & 0,125 & 0,625 & Synergetic \\
\hline$E . C$ & 0,5 & 0,125 & 0,625 & Synergetic \\
\hline E.C (lait) & 0,5 & 0,25 & 0,75 & Synergetic \\
\hline Shegilla,sp & 0,5 & 1 & 1,25 & Indifferent \\
\hline $\begin{array}{l}\text { Salmonella } \\
\text { sR }\end{array}$ & 1 & 0,125 & 1,125 & Indifferent \\
\hline
\end{tabular}

To the methanolic extract, the efficiency of the association between them and antibiotics has resulted in improving the inhibitory effect on Clostridium.sp, E.coli, E.coli and S.aureus of dairy origin. 


\section{Aqueous extract}

TABLE VIII: MIC VALUES ON E.A.U WITH THE ANTIBIOTIC

\begin{tabular}{|c|c|c|c|c|}
\hline strains & $\begin{array}{l}\text { MIC of } \\
\text { A } \\
. \mathrm{E}(\mathrm{mg} / \mathrm{ml} \\
\end{array}$ & $\begin{array}{l}\text { MIC of } \\
\text { ATB } \\
(\mu \mathrm{g} / \mathrm{ml})\end{array}$ & $\begin{array}{l}\text { MIC of A.E with } \\
\text { ATB }\end{array}$ & $\begin{array}{l}\text { MIC of } \\
\text { ATB with } \\
\text { A.E }\end{array}$ \\
\hline$S A$ & 200 & 0,5 & $25(25 / 0,25)$ & $\begin{array}{l}0,25 \\
(0,25 / 25)\end{array}$ \\
\hline SA.IVM & 25 & 0,25 & $25(25 / 0,25)$ & $\begin{array}{l}0,25 \\
(0,25 / 25)\end{array}$ \\
\hline SA.IMM & 100 & 1 & $25(25 / 0,25)$ & $\begin{array}{l}0,25 \\
(0,25 / 25)\end{array}$ \\
\hline $\begin{array}{l}\text { Clostridiu } \\
\text { m.sp }\end{array}$ & 200 & 1 & $25(25 / 0,5)$ & $\begin{array}{l}0.5 \\
(0,5 / 25)\end{array}$ \\
\hline E.C & 150 & 4 & $75(75 / 1)$ & $1(1 / 75)$ \\
\hline E.C (lait) & 25 & 1 & $50(50 / 2)$ & $1(1 / 25)$ \\
\hline Shegilla.sp & 100 & 8 & $25(25 / 1)$ & $1(1 / 25)$ \\
\hline $\begin{array}{l}\text { Salmonell } \\
\text { a.sp }\end{array}$ & 100 & 8 & $25(25 / 1)$ & $2(2 / 50)$ \\
\hline
\end{tabular}

TABLE 18: CALCULATION OF THE FIC INDEX BETWEEN A.E AND ATB

\begin{tabular}{|c|c|c|c|c|}
\hline Strains & $\mathrm{FIC}_{\mathrm{AE}}$ & FIC $_{\text {ATB }}$ & FIC $_{\text {FIN }}$ & $\begin{array}{l}\text { Nature of the } \\
\text { relation between } \\
\text { A.E and ATB }\end{array}$ \\
\hline$S A$ & 0,125 & 0,5 & 0,625 & Synergetic \\
\hline SA.IVM & 1 & 1 & 2 & Antagonist \\
\hline SA.IMM & 0,25 & 0,25 & 0,5 & Synergetic \\
\hline $\begin{array}{l}\text { Clostridium.s } \\
p\end{array}$ & 0,125 & 0,5 & 0,625 & Synergetic \\
\hline E.C & 0,5 & 0,25 & 0,75 & Synergetic \\
\hline E.C (lait) & 2 & 1 & 3 & Antagonist \\
\hline Shegilla.sp & 0,25 & 0,125 & 0,375 & Synergetic \\
\hline $\begin{array}{l}\text { Salmonella.s } \\
p\end{array}$ & 0,25 & 0,25 & 0,5 & Synergetic \\
\hline
\end{tabular}

To the aqueous extract, a positive relationship gives a better effect on the majority of pathogenic strains including Salmonella.sp, Shegilla.sp, hospital origin of E.coli, Clostridium.sp, S.aureus, SA.IMM.

The efficiency of the effect of synergy between antibiotics and different halimus Atriplex extracts can get to the increase in salinity in the aerobic part of the plant $(12 \% \mathrm{Na}+)$.

This test gives an idea about the importance of alternative medicine to fight against the emergence of multidrug resistance of bacteria to antibiotics.

\section{CONCLUSION}

In conclusion, the emergence of multidrug-resistant bacteria infections is a serious threat to humans and environment worldwide. In this study, samples from Clinical infection and Foods allowed to isolate different strains Gram positive and Gram negative bacteria pathogenic, multidrug resistant and producing beta-lactamases.

The results of the antibacterial activity of different extracts of Atriplex halimus demonstrate strongest inhibitory effect against all pathogenic strains producing beta-lactamase. Further physiochemical researches are required to identify the active molecules responsible for the inhibition effect, and to determine the mechanism of action of the plant extract on the pathogenic strains for further application as an alternative natural therapeutic antimicrobial agent .

\section{ACKNOWLEDGMENTS}

The autors would like to thank the directorate for post graduation. We are grateful to the project of CNEPRU and the Algerian Ministry of Higher Education and Scientific Research for their financial support.

\section{REFERENCES}

[1] Osmond, c. b., 0. bjorkman, and d. j. anderson. 1980. physiological processes in plant ecology: toward a synthesis with atriplex. springerverlag, berlin, frg.

[2] McArthur ed, sanderson sc. 1984. distribution, systematics, and evolution of chenopodiaceae: an overview: in:tiedemann ar, mcarthur ed, stutz hc, stevens r, johnson kl,. 1983 may 4-6; provo, ut.

[3] lucchesi me. extraction sans solvant assisté par micro-onde conception et application a l'extraction des huiles essentiel. thèse de doctorat en science discipline: chimie, université de la réunion, faculté des sciences et technologie.

[4] Escarpa a , gonzález mc . chromatographie liquide à haute performance avec détection par barrettes de diodes pour la détermination des composés phénoliques en écorce et la pulpe de différentes variétés de pommes. chromatogr a. 9 octobre 1998; 823 (1-2): 331-7.

[5] Biomerieux, marcy l'etoile -France

[6] Al-Bayati, f.a.,sulaiman,k.d.,2008. in vitro antimicrobial activityof salvadora persica extracts againstsomeisolatedoralpathogensiniraq.turkishjournalof biology $32,57-62$.

[7] Joffin $\mathrm{j} n$ et leyral g (2001) : microbiologie technique, dictionnaire des techniques. centre régional de documentation pédagogique d'aquitaine. pp: $48-49$.

[8] Courvalin, p., goldstein, f., philippon, a. and sirot, j. (1985) l'antibiogramme. paris, bruxelles: mpc-videocom.

[9] Howaida,a.f.,skaug,n.,francisgeorge,w.,2002. in vitro antimicrobial effects crudemiswakextractsonoralpathogens.saudijournalofdentistry 14,26-32.

[10] Le houérou, h.n., 1992: an overview of vegetation and land degradation in world arid lands. in: degradation and restoration of arid lands [dregne, h.e. (ed.)]. internat. center for arid and semi-arid lands studies (icasals), texas tech university, lubbock, texas, pp. 127-163.

[11] Jean-paul legros 2007 les grands sols du monde 2-88074-723-6.

[12] Longstreth, d.j., and p.s. nobel 1979 salinity effects on leaf anatomy, consequence for photosynthesis. plant physiol. 63:700-703.

[13] Parida a.k., das a.b. (2005): salt tolerance and salinity effect on plants: review. ecotoxicology and environmental safety. vol.60, pp. 324-349.

[14] Ilyas chikhi1, hocine allali1* , karima bechlaghem1, nadia fekih1, alain muselli2, nassim djabou1, mohammed el amine dib1, boufeldja tabti1, noureddine halla3, jean costa2 2013 assessment of in vitro antimicrobial potency and free radical scavenging capacity of the essential oil and ethanol extract of calycotome villosa subsp. intermedia growing in algeria asian pacific journal of tropical disease 10.1016/s2222-1808(14)60587-9 
[15] Belyagoubi.n. 2011, activité antioxydante des extraits des composés phénoliques de dix plantes médicinales de l'ouest et du sud-ouest algérien.

[16] Rybak mj. augmentation de la résistance bactérienne: protekt états-unis - une mise à jour. les annales de supplément pharmacothérapie. 2004 septembre; 38 (9): s8-s13.

[17] Philippon a., arlet g., 2006. $\beta$-lactamases de bacilles à gram négatif : le mouvement perpétuel. annales de biologie clinique. 64 (1): 37-51.

[18] Cantón $r$, novais a, valverde a, machado e, 1 peixe, baquero $\mathrm{f}$, et al. prévalence et propagation du spectre étendu de bêta-lactamase entérobactéries productrices en europe. clin microbiol infect. 2008; 14 suppl 1: 144-53.

[19] Rabaud christian dureux jean-bernard, canton philippe, may thierry, , 2010, api 2010 nancy - historique du service des maladies infectieuses du chu de nancy.

[20] Sougakoff.w., trystram .d., 2003résistances aux $\beta$-lactamines service de bactériologie-hygiène - pitié-salpêtrière .

[21] H. Benfreha temmouri , a. tirtouil meddah, t. sahraoui and b. meddah alternative treatment of methicillin-resistant staphylococcus aureus and extended spectrum beta-lactamases producing multiresistant gramnegative bacteria from nosocomial infection by marrubium vulgare methanolic compounds journal of chemical and pharmaceutical research, , 2014, 6(6):60-64 0975-7384

[22] Nadia chelli-chentouf, aicha tirtouil meddah, catherine mullie abdelkader aoues, boumediene meddah in vitro and in vivo antimicrobialactivity of algerianhoggar salvadora persica 1. extracts against microbial strains from children's oralcavity journal of ethnopharmacology (2012)144: 57-66. 